\title{
Bank Specific Factors and Bank Performance: Evidence from Nigeria
}

\author{
Ebenezer Mayowa Ariyibi ${ }^{1^{*}}$, Lateef Adewale Yunusa ${ }^{2}$, Tolulope Oyakhilome Willams ${ }^{3}$ \\ ${ }^{*}$ Corresponding author
}

\begin{abstract}
The impact of bank-specific factors on the performance of the deposit money banks in a country has been an area of inquiry for any bank-based financial system. The research investigates the impacts of bank-specific factors on bank performance in Nigeria within 2014-2018. This research use panel data from ten banks that had the best deposit in 2018. The panel data approach found a significant negative relationship between asset quality and return on asset and a significant positive relationship between loan-to-deposit ratio, capital adequacy, and return on asset. In this regard, strategic management should ensure chasing their functional intermediation role and ensure liquidity preference to meet its day-to-day obligations.
\end{abstract}

Keywords: firm-specific factors, bank performance, asset quality, panel regression

\begin{abstract}
Abstrak
Dampak faktor spesifik bank terhadap kinerja dari simpanan uang di bank pada suatu negara telah menjadi area penelitian pada sistem keuangan berbasis bank. Penelitian ini menyelidiki dampak faktorfaktor spesifik bank terhadap kinerja bank di Nigeria dalam 2014-2018. Penelitian ini mengggunakan data panel dari sepuluh bank yang memiliki kinerja penghimpunan dana terbaik pada tabun 2018. Melalui pendekatan data panel, ditemukan ada hubungan negatif yang signifikan antara kualitas aset dan pengembalian aset dan hubungan positif yang signifikan antara rasio pinjaman terhadap deposito, kecukupan modal, dan pengembalian aset. Dalam hal ini, manajemen strategis harus memastikan mengejar peran intermediasi fungsional mereka dan memastikan preferensi likuiditas dapat memenuhi kewajibannya sehari-hari.
\end{abstract}

Kata Kunci: faktor spesifik perusahaan, kinerja bank, kualitas aset, regresi panel

JEL Classification: G21, G32, C33

How to Cite:

Ariyibi, E. M., Yunusa, L. A., \& Williams, T. O. (2020). Bank Specific Factors and Bank Performance: Evidence from Nigeria. Signifikan: Jurnal Ilmu Ekonomi, 9(2), 167-176. https://doi.org/10.15408/sjie.v9i2.14658. 


\section{Introduction}

Financial intermediation is where scarce funds are channels from the savers to the borrowers in the financial sector. The bank is a player in the function of financial intermediation in the economy. The banking sector is the propellant of the financial and economic accelerator using their money creation and money destroying abilities in the country. The bank is an essential provider of funds, and its stability is relevant and critical for financial development and growth of the economy (Menicucci \& Paolucci, 2016). A country can also preserve or drive itself from an undesirable crisis when the nation operates a sound, profitable, efficient, and well-managed banking system.

The banking industry contributes to the financial development by aiding increasing efficiency of saving mobility and resources allocation to productive sectors in the economy (Greenwood et al., 2010). In the long run, these stimulate economic growth by promoting risk-sharing and reducing agency costs in the economy (Shleifer \& Vishny, 2010). Bank Specific factors or internal factors are the individual bank attributes that influence bank efficiency towards savers and borrowers of the fund in the economy. These factors influence the internal decision of the management and board. These factors are within the circumference of operation for the bank to manipulate them, and they differ from bank-to-bank. These factors include capital, size of deposit liabilities, the composition of the credit portfolio, Interest rate policy, labor productivity, state of information technology, risk level management quality, bank size, and ownership, among others (Dang, 2011). All these individual bank attributes tend to influence bank performance either in terms of Asset Quality (growth deposit, bank size, and credit risk) or Liquidity Ratio (loan ratio, deposit ratio, and interest expenses) (Kassem \& Sakr, 2018; Roman \& Sargu, 2015).

Deposit Money banks play a vital role in the allocation of resources in the economy, by serving as the hub that transfer resources from the surplus sector to the deficit sector via the interchange of the interest paid and interest charged in the internal environment of the banks (Ongore \& Kusa, 2013). Therefore, the sustainable intermediation prowess of the deposit money bank has a critical implication for the economic growth of any country in which its economy is bank-based like Nigeria and most developing countries. Despite the importance of this unit in the financial sector, a poor performance level can lead to bank failure and crisis, which will stunt the savings and investment unit that stimulates the flow of funds in the economy (Al-Tamimi, 2010).

The liquidity - profitability trade-off theory also posits the relevance of liquidity (current ratio) that is an essential internal component of the bank, which has a germane impact on the overall performance of the deposit money bank. The theory states that both liquidity and profitability can be termed performance parameters for the banks are both sides of the coin, mutually inclusive of each other in the overall relevance of the banking industry. Both are not meeting a consensus that will lead to cash flight and reduction in depositor's confidence, which will stunt the financial sector growth and development (Bagyenda et al., 2011).

The internal or micro specific variable is the variable that can be manipulated by the board or management of the bank. In finance, we refer to them as idiosyncratic factors of a 
firm. Demirguc-Kunt \& Maksimovic (1999) show that the extent to which various financial, legal, and other factors (example: corruption) affect bank profitability is closely related to the internal specifics of size. While the size is closely related to banks' capital adequacy, imploring that small banks tend to raise high and expensive capital, which in the large or long-run reduces profitability.

The need for risk management in the banking sector is an essential phenomenon in the banking business's investment-savings gap. The poor asset quality and low levels of liquidity are two significant causes of bank failure. During periods of increased uncertainty, financial institutions may decide to diversify their portfolio and/or raise their liquidity to reduce their risk. In this respect, risk can divide into credit/asset risk and liquidity risk that have components of bank-specific variables that affect the performance of banks if not effectively managed and utilized.

Bank profitability is a measure of the amount in which bank return on investment exceeds its investment cost. Bank profitability is also a crucial objective to conduct business without which money deposit banks will not be in business. A firm's gross profit margin and net profit margin depicts its profitability position (Umobong, 2010). Bank profitability can be expressed as a function of internal and external environments or Bank profitability could be a function of internal and external environments. The internal determinants originate from balance sheets and/or profit and loss accounts, while external determinants are variables that are related to bank management but reflect the economic and legal environment that affects the operation and performance of financial institutions. With excellent profit figures, banks can enhance their stakeholders; maximize shareholder wealth, and stay competitive in the financial market.

However, to achieve their desired level of profits, banks are confronted with several factors that are either internal or external. Bank profitability is not only assessed at a specific level but also the general-level. At the specific level, profit is a relevant component of competitive banking institutions, as it is a pre-requisite for banking institutions to grow and remain a going concern in the financial sector. The primary purpose of bank-specific factors is profit realization which is germane to the existence and minimization of cost to the bank. Profit is a financial motive in an organization (Menicucci \& Paolucci, 2016). The importance of profit at a general level is that a profitable banking sector has a better ability to endure negative shock (National and Global) and aid the growth of the economy.

Bank Specific factors are the variables within the bank's internal environment that the banks can manipulate to their benefits and differ from bank-to-bank. These factors have always been mixed-up with some industry-specific and macro-economic factors (Industry-specific or macro-economic factors are factors that affect the bank from its exposure to the external environment while performing the development function of intermediation). Due to this discrepancy in literature, this study will enquire only on the internal or bank-specific factors that affect bank performance without including any industry-specific factor. Studies like Kamande et al. (2017), Kassem \& Sakar (2018), and Rahman et al. (2015) have found out in their studies that profitability (either use ROE 
or ROA) has a positive relationship with all camel specification and liquidity proxies. Also, in the process of reviewing Athanasoglu et al. (2005), Kamande et al. (2017), Dang (2011), and Akhtar et al. (2011), it was observed that asset quality and liquidity has some other internal financial ratios attributable to both phenomena. Asset quality from the holistic view includes bank size, credit risk, and loan loss ratio to total gross loan, while liquidity has a holistic view of loan ratio, deposit ratio, and interest expenses ratio. This study employs the return on the asset that is a managerial capability proxy of performance. It is a managerial accuracy proxy that will help managers in the bank understand asset quality proxy and liquidity proxy that positively or negatively influence their performance.

The study of bank-specific factors on performance shows different results, and this shows that there is a problem on the topic. Therefore, this study contributes to testing specific bank factors on bank performance in Nigeria. Therefore, this study examines the impact of bank-specific factors on bank performance by using panel regression (random and fixed effect regression model).

\section{Methods}

This study aims to analyze the impact of bank-specific factors on bank performance in Deposit money banks in Nigeria, utilizing some components from the study of Akhtar et al. (2011), Amuer \& Mhiri (2013). Thus this study uses a major model as follows:

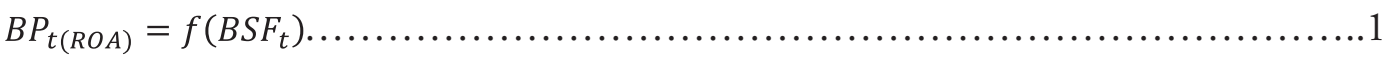

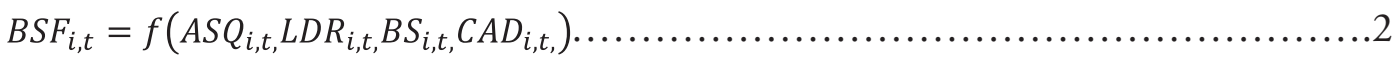

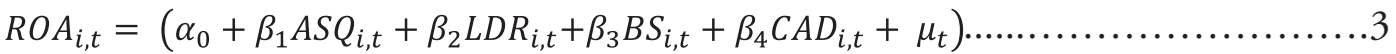

The dependent variable is ROE (Return on asset). In order to measure the bank-specific factors, the independent variable in the models includes:

ASQ is asset quality at time t,

LDR is loan on deposit ratio at time $t$,

BS is board size at time $t$, and

CAD is capital adequacy at time $t$.

The study employed the ex-post facto research design. The panel data covers a period of ten years (10) from 2014-2018. The study populations consist of all twenty-three listed deposit money banks quoted on the Nigeria Stock Exchange. The deposit money banks include First Bank of Nigeria, Zenith Bank PLC, Access Bank, United Bank of Africa, Ecobank, Standard Chartered, Stanbic IBTC, Mainstreet Bank, Enterprise Bank, and Union Bank. The above banks choose in terms of the respective tiers they are according to Basel Accord. 


\section{Results and Discussions}

Table 1 depicted the descriptive statistics used in the study. Return on asset (ROA) has a mean value of $0.02 \%$, a median value of $0.14 \%$ and a standard deviation with a variation value of 0.01 . Return on equity (ROE) has a mean value of $0.14 \%$, a median value of $0.15 \%$, and Standard deviation has a variation of 0.09 . Asset quality (ASQ) has a mean value of $0.06 \%$, the median value of $0.04 \%$, and Standard deviation has a variation value of 0.04 . Loan deposit ratio (LDR) has a mean value of $0.71 \%$, a median value of $0.70 \%$, and the standard deviation has a variation value of 0.15 . Board size (BS) has a mean value of $8.87 \%$, a median value of $9.19 \%$, and standard deviation has a variation value of 1.17 . Capital adequacy ratio (CAR) has a mean value of 0.12 ; the median value of 0.12 and the standard deviation has a variation value of 0.03 .

Table 1. Descriptive Analysis

\begin{tabular}{lcccccc}
\hline & ROA & ROE & ASQ & LDR & BS & CAR \\
\hline Mean & 0.022116 & 0.145017 & 0.063854 & 0.714460 & 8.870075 & 0.123530 \\
Median & 0.024795 & 0.159750 & 0.045399 & 0.707757 & 9.198211 & 0.121913 \\
Maximum & 0.052987 & 0.335796 & 0.220000 & 1.144260 & 10.25393 & 0.235976 \\
Minimum & -0.005388 & -0.097763 & 0.022975 & 0.455865 & 6.574640 & 0.073105 \\
Std. Dev. & 0.013090 & 0.099663 & 0.044051 & 0.155524 & 1.179616 & 0.037926 \\
Skewness & -0.073579 & -0.205829 & 1.624630 & 0.531304 & -1.078934 & 1.361945 \\
Kurtosis & 2.517412 & 2.498746 & 5.681734 & 2.946366 & 2.771974 & 5.074791 \\
Jarque-Bera & 0.530305 & 0.876497 & 36.97790 & 2.358355 & 9.809154 & 24.42570 \\
Probability & 0.767089 & 0.645166 & 0.000000 & 0.307532 & 0.007413 & 0.000005 \\
Sum & 1.105807 & 7.250841 & 3.192718 & 35.72299 & 443.5037 & 6.176505 \\
Sum Sq. Dev. & 0.008396 & 0.486698 & 0.095085 & 1.185199 & 68.18316 & 0.070482 \\
Observations & 50 & 50 & 50 & 50 & 50 & 50 \\
\hline
\end{tabular}

Return on asset (ROA has a minimum value of -0.00 and a maximum value of 0.33 . Next, asset quality has a minimum of 0.02 and a maximum value of 0.22 . LDR has a minimum value of 0.45 and a maximum value of 10.2. CAR has a minimum value of 0.07 and a maximum value of 0.23 . The Skewness in the variable includes: ROA is negatively skewed at $-0.07, \mathrm{ROE}$ is negatively skewed at -0.20 , ASQ is positively skewed at 1.62 , LDR is positively skewed at 0.53 , BS is negatively skewed -1.07 and CAR is positively skewed at 1.36 . The Kurtosis in the variable includes: ROA is leptokurtic at 2.51, ROE is leptokurtic at 2.49, ASQ is platykurtic at 5.68, LDR is leptokurtic at 2.94, BS is leptokurtic at 2.77 and CAR 5.07. The Jarque-Bera Statistics conclude that all variables are normally distributed. 
Table 2. Correlation Table

\begin{tabular}{ccccccc}
\hline & ROA & ROE & ASQ & LDR & BS & CAR \\
\hline ROA & 1 & & & & & \\
ROE & 0.90 & 1 & & & & \\
ASQ & 0.01 & 0.04 & 1 & & & \\
LDR & 0.01 & 0.18 & -0.05 & 1 & & \\
BS & -0.20 & -0.19 & 0.24 & -0.22 & 1 & \\
CAR & 0.14 & -0.03 & 0.18 & -0.27 & -0.25 & 1 \\
\hline
\end{tabular}

Table 2 shows that ROA has a positive relationship with ASQ (Asset quality) at 0.01, LDR at 0.01 , and CAR at 0.14 . ROA has a negative relationship with BS at -0.20 . ROE has a positive relationship with ASQ and LDR; meanwhile, ROE has a negative relationship with BS and CAR. Table 2 depicts that return on the asset has a positive relationship with asset quality, loan to deposit ratio, and capital adequacy ratio, but a negative relationship with board size. All other independent variable does not have a multicollinear relationship with each other at 0.80 .

The result shows the Hausman test diagnostic that depicts the appropriate forecasting model. The result shows that the appropriate forecasting model is the random effect as the Hausman test with F (p-value) of 0.2300 shows the acceptance of the alternative hypothesis of the random effects. Hence, we accept the estimation of random effect for forecasting. There is a need to check the appropriateness of the random-effect model further.

The pooled regression model result shows that the variables that affect the profitability are asset quality, the board size, and capital adequacy ratio. Asset quality and capital adequacy ratio have a positive relationship with profitability that proxy by ROA. The board size has a negative relationship with return on asset. On the other hand, the loan to deposit ratio does not affect the level of profitability.

The fixed-effect model depicts that asset quality, loan to deposit ratio, and capital adequacy ratio affect the bank's performance measured by ROA. On the other hand, board size does not have an impact on ROA. The capital adequacy ratio and loan to deposit ratio have a positive relationship on return on asset. Otherwise, the asset quality has a negative relationship on return on asset. The coefficient of determination using adjusted R2 shows that the explanatory variables (ASQ, LDR, BS, and CAD) explained $47.13 \%$ percent variation in deposit money banks in Nigeria. That is, $45.02 \%$ is explained by other variables not included in the model. The model's overall statistical level depicts that the model is suitable for forecasting, giving the F-statistics of 13.039. Since the p-value is less than 0.05 , hence we conclude that the model is statistically significant and brings about the rejection of the null hypothesis. This result means that asset quality, loan to deposit ratio, board size, and capital adequacy ratio have a significant effect on Nigeria's deposit money banks. 
Table 3. Regression Analysis

\begin{tabular}{cccc}
\hline Variable & Pooled & Fixed & Random \\
\hline C & 0.0374 & 0.0487 & 0.0257 \\
& $(0.1405)$ & $(0.7486)$ & $(0.5008)$ \\
ASQ & 0.0157 & -0.0366 & -0.0338 \\
& $(0.0345)^{*}$ & $(0.0108)^{*}$ & $(0.0789)^{* *}$ \\
LDR & -0.0043 & 0.0020 & 0.0020 \\
& $(0.9743)$ & $(0.0966)^{* *}$ & $(0.0344)^{*}$ \\
BS & -0.0022 & -0.0041 & -0.0014 \\
& $(0.0363)^{*}$ & $(0.8135)$ & $(0.7083)$ \\
CAD & 0.0298 & 0.0868 & 0.0802 \\
& $(0.0064)^{*}$ & $(0.0336)^{*}$ & $(0.0742)^{* *}$ \\
\hline$R^{2}$ & 0.5053 & 0.8738 & 0.4710 \\
Adjusted R & 0.4886 & 0.8068 & 0.4502 \\
Durbin Watson & 0.3527 & 1.8554 & 1.5905 \\
F-Statistics & 0.6593 & 13.039 & 1.1263 \\
Prob (F-statistics) & 0.6234 & 0.0000 & 0.3560 \\
Hausman Test & 0.2300 & & \\
\hline
\end{tabular}

$p<0.05^{*} ; p<0.1^{* *}$

The random effect model shows that the variables that impacted bank performance are asset quality, loan to deposit ratio, and capital adequacy ratio. Otherwise, the board size does not have an impact on bank performance. The capital adequacy ratio has a positive relationship on return on asset. However, the asset quality and loan to deposit ratio has a negative relationship on bank performance. The coefficient of determination using adjusted R2 shows that the explanatory variables (ASQ, LDR, BS, and CAD) explained $47.10 \%$ percent variations in Nigeria's deposit money banks. That is, $52.9 \%$ is explained by other variables not included in the model. The model's overall statistical level depicts that the model is suitable for forecasting giving the F-statistics of 1.126. Since the p-value is high than 0.05 , we conclude that the model is statistically insignificant and brings about the null hypothesis's acceptance. These findings mean that asset quality, loan to deposit ratio, the board size, and capital adequacy ratio have no significant effect on deposit money banks in Nigeria.

The finding of asset quality is consistent with the study of Rahman et al. (2015) and Kamande et al. (2017), which revealed that the bank's asset/deposit component has a significant effect on the profitability of the banks. Nevertheless, this result is inconsistent with the study by Kassem \& Sakr (2018) that illustrate a non-significant impact on banks' performance. Poor asset quality will negatively impact banks' profitability (Salike \& Ao, 2018). Ali et al. (2011) suggest that efficient asset management will positively impact profitability.

The liquidity ratio that is proxies by the loan to deposit ratio shows the effect on the bank's performance. This research shows that the loan deposit ratio has a positive impact on profitability. The positive relationship between loans to deposit ratio on profitability is consistent with Supriyono \& Herdhayinta (2019). This result differs from Kusmayadi 
(2018), which found a negative relationship between the loans to the deposit ratio and profitability. Sari \& Murni (2016) also find a different result with this result, and they find that loans to deposit ratio do not have an impact on profitability.

The board size finding is also inconsistent with Akinkumi (2017) study that illustrated that bank size has a positive effect on bank performance. Kassem \& Sakr (2018) also depict that bank size has a significant relationship with profitability. Staikouras et al. (2007) and Dogan \& Yildiz (2013) find a negative relationship between board size and return on assets.

This result shows that the capital adequacy ratio has a significant impact on profitability. Nguyen (2020) finds an impressive result that the capital adequacy ratio has a positive impact on small-sized banks' profitability. Meanwhile, the capital adequacy ratio has no impact on profitability for large-sized banks. Tangngusalu et al. (2020) also find a different result, in which the capital adequacy ratio does not impact the return on assets.

El-Anshary \& Megahed (2016) suggest that banks with higher capital strength, asset share, and efficient management will have a higher profitability level. Otherwise, banks with higher credit risk and loans will exhibit lower profitability levels. Alper \& Anbar (2011) suggest that banks should increase the bank size to improve their profitability. Islam et al. (2017) suggest that banks diversify banking activities, including investment activities, to have more profit.

\section{Conclusion}

The research provides empirical estimation results in examining the impacts of bankspecific factors on the performance of deposit money banks in Nigeria. The equation of model 3 depicts that asset quality has a significant negative effect on bank performance. These findings show that the performance level of a bank influence by the performance of the banks' physical and deposit quality. The findings also illustrate that the loan-to-deposit ratio has a positive effect on bank performance. So, the level of deposit to the amount of loan given at a particular interest rate in the bank can determine the bank's overall performance. The findings also depict that the capital adequacy ratio has a positive effect on bank performance. It means that the adequacy prowess (ability to meet daily financial obligations) has an impact on improving the performance and eradication of capital flight among the bank customers and also reduces financial exclusion among savers and depositors.

Therefore, the internal environment or the strategic level management in the banks should make sure the loan to deposit ratio maintain according to the regulatory balance and make sure the loan granted via their intermediation role is performing and bringing in the expected return on investment as at when due. The bank should make sure the capital adequacy maintain at always according to the Basel accord requirement and to disallow the retarding position in economic development and growth due to inadequate or low capital adequacy status in a bank.

\section{References}

Agbada, A. O., \& Suji, C. C. (2013). The Efficacy of Liquidity Management and Banking Performance in Nigeria. International Review of. Management and Business Research. (2) 1. 223-233. 
Akhtar, M. F., Ali, K., \& Sadaqat, S. (2011). Liquidity Risk Management: A Comparative Study Between Conventional and Islamic Banks of Pakistan. Interdisciplinary Journal of Research in Business, 1(1), 35-44.

Ali, K., Akhtar, M. F., \& Ahmed, H.Z. (2011). Bank Specific and Macroeconomic Indicators of Profitability: Empirical Evidence from the Commercial Banks of Pakistan. International Journal of Business and Social Science, 2(6), 235-242.

Alper, D., \& Anbar, A. (2011). Bank Specific and Macroeconomic Determinants of Commercial Bank Profitability: Empirical Evidence from Turkey. Business and Economics Research Journal, 2(2), 139-152.

Al-Tamimi, H. A. H. (2005). The Determinants of the UAE Commercial Banks' Performance: A Comparison of the National and Foreign Banks. Journal of Transnational Management, 10(4), 35-47. https://doi.org/10.1300/j482v10n04_03.

Ameur, I. G. B., \& Mhiri, S. M. (2013). Explanatory Factors of Bank Performance in Tunisia: a Panel Model Approach. Global Journal of Management and Business Research Finance, 13(5), 1-12.

Athanasoglou, P. P., Brissimis, S. N., \& Delis, M. D. (2005). Bank-Specific, Industry-Specific and Macroeconomic Determinants of Bank Profitability. Working paper No. 25, Bank of Greece.

Bagyenda, J., Brownbridge, M., \& Kasekende, L. (2011). Basel III and the Global Reform of Financial Regulation: How Should Africa Respond? a Regulator's Perspective. New Rules for Global Finance, 3(5), 123-135.

Dang, U. (2011). The CAMEL Rating System in Banking Supervision: A Case Study. (Unpublished Thesis). Arcada University of Applied Sciences.

Demerguç-Kunt, A., \& H. Huizinga. (1999). Determinants of Commercial Bank Interest Margins and Profitability: Some International Evidence. World Bank Economic Review. 13(2), 379- 408.

Dogam, M., \& Yildiz, F. (2013). The Impact of the Board of Directors' Size on the Bank Performance: Evidence from Turkey. European Journal of Business and Management, 5(6), 130-140.

El-Ansary, O., A., \& Megahed, M., I. (2016). Determinants of Egyptian Banks Profitability Before and After Financial Crisis. Corporate Ownership and Control, 14(1), 360-372.

Greenwood, J., Sanchez, J. M., \& Wang, C. (2010). Financing Development: The Role of Information Costs. American Economic Review, 100(4), 1875-1891. https://doi. org/10.1257/aer.100.4.1875.

Islam, M. A., Sarker M., N., Rahman M., Sultana, A., \& Prodhan, AZM. S. (2017). Determinants of Profitability of Commercial Banks in Bangladesh. International Journal of Banking and Financial Law, 1(1), 1-11.

Kamande, E. G., Zablon, E., \& Ariemba, J. M. (2017). The Effect of Bank Specific Factors on Financial Performance of Commercial Bank in Kenya. International Journal of Sciences: Basic and Applied Research, 30(5), 165-180. https://doi.org/10.7176/rjfa/10-20-14. 
Kassem, N., M. \& Sakr, A., (2018). The Impact of Bank Specifics on the Profitability of Commercial Bank. Journal of Finance and Bank Management, 6(2), 76-90. https://doi. org/10.15640/jfbm.v6n2a8.

Kusmayadi, D. (2018). Analysis of Effect of Capital Adequacy Ratio, Loan to Deposit Ratio, Non Performing Loan, BOPO, and Size on Return on Assets in Rural Banks at Indonesia. Saudi Journal of Business and Management Studies, 3(7), 786-795.

Menicucci, E., \& Paolucci, G., (2016). The Determinants of Bank Profitability: Empirical Evidence from European Banking Sector. Journal of Financial Reporting and Accounting, 14(1), 86-115. https://doi.org/10.1108/JFRA-05-2015-0060.

Nguyen, T. H. (2020). Impact of Bank Capital Adequacy on Bank Profitability Under Basel II Accord: Evidence from Vietnam. Journal of Economic Development, 45(1), 31-46.

Ongore, V. O., \& Kusa, G. B. (2013). Determinants of Financial Performance of Commercial Banks in Kenya. International Journal of Economics and Financial Issues, 3(1), 237-252.

Rahman, M. M., Hamid, M. K., \& Khan, M. A. (2015). Determinants of Bank Profitability: Empirical Evidence from Bangladesh. International Journal of Business and Management, 10(8), 135-150. https://doi.org/10.5539/ijbm.v10n8p135.

Roman, A., \& Sargu, A. C. (2015). The Impact of Bank-Specific Factors on the Commercial Banks Liquidity: Empirical Evidence from CEE Countries. Procedia Economics and Finance, 20, 571-579. https://doi.org/10.1016/S2212-5671(15)00110-0.

Salike, N., \& Ao, B. (2018). Determinants of Banks' Profitability: Role of Poor Asset Quality in Asia. China Finance Review International, 8(2), 216-231. https://doi.org/10.1108/ CFRI-10-2016-0118.

Sari, Y. A. N., \& Murni, N. S. I. M. (2016). Analysis of The Effect of Third Party Fund, Capital Adequacy Ratio, and Loan to Deposit Ratio on Bank's Profitability After the Application of IFRS. The Indonesian Accounting Review, 6(1), 81-90. https://doi. org/10.14414/tiar.v6i1.577.

Shleifer, A., \& Vishny, R. (2010). Unstable Banking. Journal of Financial Economics, 97(3), 306-318. https://doi.org/10.1016/j.jfineco.2009.10.007.

Staikouras, P. K., Staikouras, C. K., \& Agoraki, M. E. K. (2007). The Effect of Board Size and Composition on European Bank Performance. European Journal of Law and Economics, 23, 1-27. https://doi.org/10.1007/s10657-007-9001-2.

Supriyono, R. A., \& Herdhayinta, H. (2019). Determinants of Bank Profitability: The Case of the Regional Development Bank (BPD Bank) in Indonesia. Journal of Indonesian Economy and Business, 34(1), 1-17.

Tangngisalu, J., Hasanuddin, R., Hala, Y., Nurlina., \& Syahrul, S. (2020). Effect of CAR and NPL on ROA: Empirical Study in Indonesia Banks. The Journal of Asian Finance, Economics, and Business, 7(6), 9-18. https://doi.org/10.13106/jafeb.2020.vol7.no6.009.

Umobong, A. A. (2.015). Assessing the Impact of Liquidity and Profitability Ratios on Growth of Profits in Pharmaceutical Firms in Nigeria. European Journal Accounting, Auditing and Finance, 3(10), 97-114. 